\title{
Characterization of sugarcane (Saccharum spp.) leaf senescence: implications for biofuel production
}

\author{
Maria Thereza Bazzo Martins ${ }^{1,2 \dagger}$, Wagner Rodrigo de Souza ${ }^{1 \dagger}$, Bárbara Andrade Dias Brito da Cunha', \\ Marcos Fernando Basso', Nelson Geraldo de Oliveira' ${ }^{1}$, Felipe Vinecky ${ }^{1}$, Polyana Kelly Martins', \\ Patrícia Abrão de Oliveira ${ }^{3}$, Bruna Cersózimo Arenque-Musa ${ }^{4}$, Amanda Pereira de Souza ${ }^{4}$, \\ Marcos Silveira Buckeridge ${ }^{4}$, Adilson Kenji Kobayashi ${ }^{1}$, Betania Ferraz Quirino ${ }^{1,2}$ \\ and Hugo Bruno Correa Molinari ${ }^{1 *}$
}

\begin{abstract}
Background: Second-generation ethanol (2G-bioethanol) uses lignocellulosic feedstocks for ethanol production. Sugarcane is one among the most suitable crops for biofuel production. Its juice is extracted for sugar production, while sugarcane bagasse, straw, and senescing leaves are considered industrial waste. Senescence is the agedependent deterioration of plant cells, ultimately leading to cell death and completion of the plant life cycle. Because senescing leaves may also be used for biofuel production, understanding the process of natural senescence, including remobilization of nutrients and its effect on cell walls can provide useful information for 2G-bioethanol production from sugarcane leaves.
\end{abstract}

Results: The natural senescence process in leaves of the commercial sugarcane cultivar RB867515 was investigated. Senescence was characterized by strong reduction in photosynthetic pigments content, remobilization of the nutrients $\mathrm{N}, \mathrm{P}, \mathrm{K}, \mathrm{B}, \mathrm{Cu}, \mathrm{Fe}$, and $\mathrm{Zn}$, and accumulation of $\mathrm{Ca}, \mathrm{S}, \mathrm{Mg}, \mathrm{B}, \mathrm{Mn}$, and Al. No significant changes in the cell-wall composition occurred, and only small changes in the expression of cell wall-related genes were observed, suggesting that cell walls are preserved during senescence. Senescence-marker genes, such as SAG12-like and XET-like genes, were also identified in sugarcane and found to be highly expressed.

Conclusions: Our study on nutrient remobilization under senescence in a vigorous sugarcane cultivar can contribute to the understanding on how nutrient balance in a high-yielding crop is achieved. In general, neutral monosaccharide profile did not change significantly with leaf senescence, suggesting that senescing leaves of sugarcane can be as a feedstock for biofuel production using pretreatments established for non-senescing leaves without additional efforts. Based on our findings, the potential biotechnological applications for the improvement of sugarcane cultivars are discussed.

Keywords: Sugarcane, Nutrient remobilization, Natural leaf senescence, Cell wall, Lignocellulosic ethanol, Renewable energy, Biotechnology

\footnotetext{
*Correspondence: hugo.molinari@embrapa.br

${ }^{\dagger}$ Maria Thereza Bazzo Martins and Wagner Rodrigo de Souza contributed equally to this work

1 Genetics and Biotechnology Laboratory, Embrapa Agroenergy (CNPAE),

Brasília, DF 70770-901, Brazil

Full list of author information is available at the end of the article
} 


\section{Background}

The use of ethanol from renewable sources is extremely important to reduce greenhouse gas emissions and dependence on fossil fuels [1]. Biofuels are less polluting with respect to emission of sulfur, lead, and greenhouse gases $\left(\mathrm{CO}_{2}\right.$ and $\left.\mathrm{CH}_{4}\right)$ [2]. Thus, there is a tendency to increase the demand for ethanol by increasing the use of biofuels. Several efforts have been made to develop alternative technologies for ethanol production from lignocellulosic biomass [3-5]. This technology, called second-generation ethanol (2G-bioethanol) production, aims to disrupt plant cell-wall polysaccharides, such as cellulose and hemicelluloses into smaller fermentable sugars and utilize them to produce ethanol $[6,7]$. However, lignocellulosic biomass is highly recalcitrant to deconstruction due to the rigid and compact structure of the plant cell wall $[5,8,9]$. Nowadays, the disruption of cell walls during 2G-bioethanol production is made mainly using chemical or enzymatic pretreatments, which increases significantly the cost of this process [7, $10,11]$.

Brazil is the largest sugarcane producer worldwide, and its production is intended mainly for ethanol and sugar production [12]. According to CONAB [13] and UNICA [14], Brazil is also the largest producer of ethanol from biomass, through sucrose fermentation. Furthermore, the potential for 2G-bioethanol production using the residue materials, such as bagasse and leaves, is enormous for sugarcane. Currently, the biomass left in the form of bagasse and leaves has the potential to increase ethanol production by approximately $40 \%$ [7]. However, one of the key problems to release the sugars from cell walls for fermentation has been recalcitrance, i.e., the difficulty to access all the linkages among carbohydrates and phenylpropanoids that need to be broken to hydrolyze the cell walls $[7,9,15,16]$.

Recently, Tavares et al. [17] and Grandis et al. [18] proposed that endogenous degradation systems could be used to help decrease cell-wall recalcitrance and facilitate production of $2 \mathrm{G}$-bioethanol. Some natural cell wall degrading processes may occur in plant cells, and such degradation appears to be preceded by programmed cell death (PCD). Because senescence is a type of PCD, the understanding of senescence-related processes could lead to the discovery of genes related to such mechanisms, and these could be used to engineer plants that would induce tissues to modify their own walls thus facilitating $2 \mathrm{G}$ ethanol production.

Senescence is the age-dependent deterioration of plant cells, ultimately leading to cell death and completion of the plant life cycle. In addition to the natural senescence process, biotic and abiotic factors are known to activate senescence pathways [19]. Leaf senescence constitutes the final stage of leaf development, and the earliest and most important event during this process is the chloroplast degradation $[20,21]$. Consequently, a decrease in the photosynthetic rate and chlorophyll content occurs, with subsequent leaf yellowing [22]. During senescence, some compounds released from degraded chloroplasts and other organelles are remobilized to other developing tissues, such as young leaves or fruits, and grains $[20,21]$. Senescence is a tightly controlled process, and, therefore, many senescence-associated genes are upregulated during this process $[19,23]$. To our knowledge, the senescence process in sugarcane has not been investigated so far. We believe that the study of the sugarcane leaf senescence can contribute not only to the understanding of this important natural process, but also to the development of new strategies to control it, improving agricultural traits of this crop. For example, studying the dynamics of synthesis and degradation of cell wall during sugarcane senescence might help in the development of biotechnological tools to assist in the bioethanol production from lignocellulosic biomass [8, 17, 24]. Moreover, plant senescence pathways can be activated by biotic and abiotic stresses, and its understanding under natural conditions offers a suitable strategy to generate transgenic crops able to cope with these stresses.

The aim of the current work was the analysis of photosynthetic pigments, nutrient remobilization, and cellwall modifications during the natural leaf senescence process in the sugarcane cv. RB867515. This cultivar has widely been used in all producing regions in Brazil, and it is characterized by drought stress tolerance, high sugar content and yield, fast growth, and great potential for lignocellulosic ethanol production [25]. We have measured these parameters not only in different leaves (from non-senescing to senescing ones), but also at different regions of the same leaf (base, middle, and tip of the leaf blade). Leaf senescence was characterized in sugarcane by reduction in photosynthetic pigment content, remobilization of some nutrients, and accumulation of others, but no significant changes in the cell-wall composition, paralleled by small changes in the cell wall-related gene expression.

\section{Methods}

\section{Plant material and sampling}

Plants of the sugarcane cv. RB867515 (Saccharum spp.) provided by Inter-University Network for Development of the Sugarcane-Ethanol Sector (RIDESA, Brazil) were maintained under field conditions at Embrapa Cerrados, from April, 2008 to December, 2008 (Planaltina, DF, Brazil; Latitude $15^{\circ} 36^{\prime} 10.7^{\prime \prime}$ and Longitude $47^{\circ} 42^{\prime} 37.7^{\prime \prime}$ ). The climate is classified as Aw type (tropical savannah; Köppen-Geiger) and is characterized by a long drought 
period. The soil of the experimental area was chemically analyzed and corrected with lime $\left(2 \mathrm{Mg} \mathrm{ha}^{-1}\right.$ of dolomitic limestone), gypsum (3 $\left.\mathrm{Mg} \mathrm{ha}^{-1}\right)$, and fertilization with nitrogen (N) $20 \mathrm{~kg} / \mathrm{ha}$, phosphorus $\left(\mathrm{P}_{2} \mathrm{O}_{5}\right) 150 \mathrm{~kg} / \mathrm{ha}$, and potassium $\left(\mathrm{K}_{2} \mathrm{O}\right) 80 \mathrm{~kg} / \mathrm{ha}$ using the chemical fertilizer NPK 04-30-16. Seven months after planting, top dressing was carried out with $\mathrm{N} 100 \mathrm{~kg} / \mathrm{ha}, \mathrm{P}_{2} \mathrm{O}_{5} 50 \mathrm{~kg} / \mathrm{ha}$, and $\mathrm{K}_{2} \mathrm{O} 100 \mathrm{~kg} / \mathrm{ha}$, using chemical fertilizer NPK 20-5-20. A leaf senescence gradient was harvested from 8-monthold plants and evaluated using the leaf numbering system proposed by Kuijper [26] (Fig. 1A). The first completely expanded leaf with visible auricle and photosynthetically active was considered as +1 leaf. In addition, to evaluate the in-leaf senescence gradient, leaves were divided in three parts: base, middle, and tip positions along the leaf blade. All analyses were conducted using plant cane.

\section{Photosynthetic pigments content}

Total chlorophyll content in +1 to +8 leaves was measured with a portable optical chlorophyll meter (SPAD502; Minolta Corporation, Tokyo, Japan) using five replicates per leaf and three readings per position of the leaf blade $(+1$ to +8 leaves at base, middle, and tip positions), and it was represented as SPAD index [27]. In addition, for +1 and +8 leaves, Chl- $a / b$ ratio and carotenoids (Cars) contents were also determined after acetone extraction as described by Henry and Grime [28]. The Chl- $a / b$ ratio and Cars content estimation were performed using extinction coefficients and equations proposed by Lichtenthaler [29].

\section{Leaf nutrient concentration}

To estimate the content of nutrients in sugarcane plants, we used the base portions of the +3 leaf blade, which is the leaf commonly used to evaluate this parameter in sugarcane [30]. The macro and micronutrients contents present in the +3 leaf were obtained from three biological replicates each composed of a leaf pool of 5 plants.

Macro and micronutrients concentrations along the leaf gradient, phosphorous $(\mathrm{P})$, potassium $(\mathrm{K})$, calcium $(\mathrm{Ca})$, magnesium $(\mathrm{Mg})$, sulfur $(\mathrm{S})$, boron $(\mathrm{B})$, copper $(\mathrm{Cu})$, iron $(\mathrm{Fe})$, manganese $(\mathrm{Mn})$, zinc $(\mathrm{Zn})$, and aluminum (Al) were obtained from leaf tissue $(+1$ to +8 leaves, each leaf blade was divided into base, middle, and tip portions) of each replicate (three replicates, each replicate consisting of five bulks collected from five different plants). The nutrient concentration profile was obtained from $1 \mathrm{~g}$ of dry mass processed by acid digestion method as described by Adler and Wilcox [31] and determined by optical emission spectrometry with inductively coupled argon plasma in Thermo Jarrell Ash spectrometer model

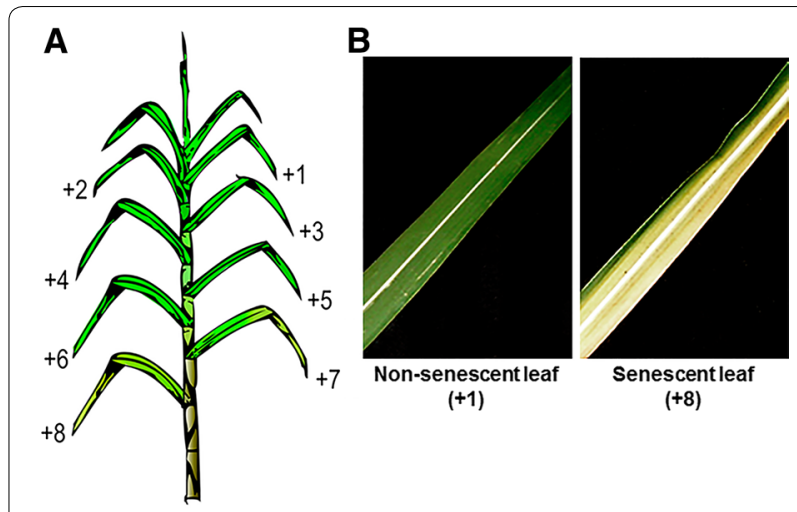

C
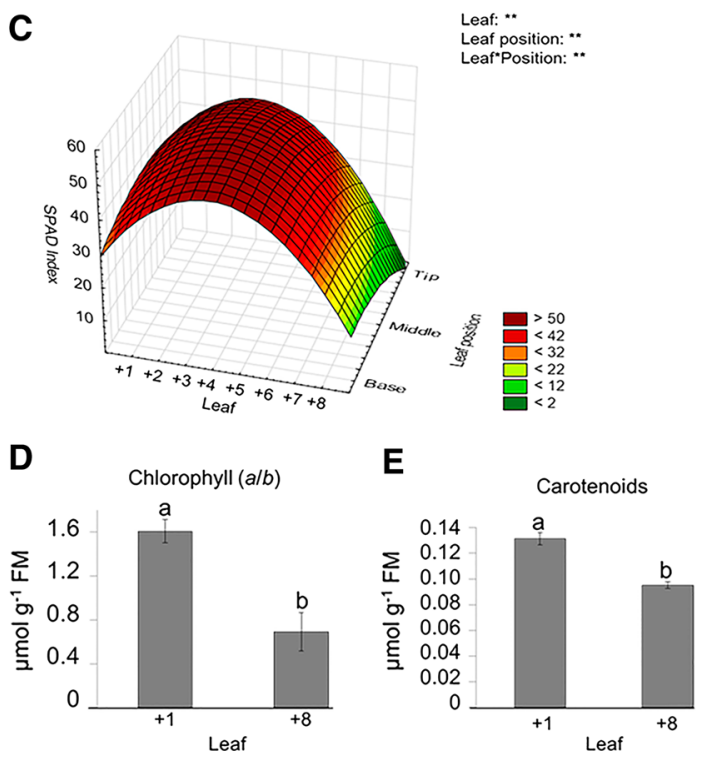

Fig. 1 Photosynthetic pigment content in sugarcane leaves CV. RB867515. A Representative scheme of a sugarcane plant depicting the leaf senescence gradient. Leaves were numbered according to the system proposed by Kuijper [26]. B Non-senescent (+1) and senescent (+8) leaves of 8-month-old sugarcane cv. RB867515. C

Three-dimensional plot of the SPAD index changes in the 'betweenleaves' gradient and the 'in-leaf' gradient ( $n=5$; read per position/ leaf $=3$ ); Statistical analysis: leaf refers to statistics applied to different leaves (from +1 to +8 ); leaf position refers to statistics applied to the same leaf (base, middle and tip portions) and leaf * position refers to statistics applied to the whole data set ('between-leaves' and 'in-leaf' gradients); asterisk indicates statistical difference: ${ }^{* *} p \leq 0.01$, ${ }^{*} p \leq 0.05$, and $n s$ non-significant; The ANOVA and significant $p$ values are available in the Additional file 2. D Chlorophyll $a / b$ ratio and E carotenoids content in sugarcane leaves; Statistical differences $(p \leq 0.05)$ were obtained with ANOVA followed by Tukey's test; Different letters indicate statistical significance at $p \leq 0.05$. FM fresh mass. Vertical bars show \pm S.E. for $n=3$

IRIS/AP, as described by Murad et al. [25]. Leaf nitrogen concentration was measured by colorimetry using the distillation method in Kjeldahl semi-micro apparatus, as described by Persson et al. [32]. 


\section{Neutral monosaccharide composition}

Leaves +1 to +8 were divided into base, middle, and tip portions of the leaf blade, and each replicate consisted of five different plants. All analyses were based on the procedures described by De Souza et al. [33]. The material was freeze-dried and ground into a fine powder in a ball mill. Five hundred milligrams of each sample were subjected to six consecutive extractions with $25 \mathrm{~mL}$ of $80 \%(\mathrm{v} / \mathrm{v})$ ethanol at $80{ }^{\circ} \mathrm{C}$ for $20 \mathrm{~min}$. Each extraction was followed by centrifugation $(10 \mathrm{~min}$ at $8500 \mathrm{~g})$, and the supernatant was discarded to remove the soluble sugars. The absence of soluble sugars was confirmed by the phenol-sulfuric method described by Dubois et al. [34]. The cell-wall extract samples were hydrolyzed with $2 \mathrm{M}$ trifluoroacetic acid (TFA) for $1 \mathrm{~h}$ at $120^{\circ} \mathrm{C}$. The acid was evaporated under vacuum and the monosaccharides were resuspended in $2 \mathrm{~mL}$ of ultra-purified water. Neutral monosaccharide profile was analyzed by high-performance anion exchange chromatography with pulsed amperometric detection (HPAEC-PAD) on a CarboPac SA10 column (DX-500 system, Dionex ${ }^{\mathrm{TM}}$ ) using a mixture of $99.2 \%$ water and $0.8 \%(\mathrm{v} / \mathrm{v}) 150 \mathrm{mM} \mathrm{NaOH}$ as eluent $\left(1 \mathrm{~mL} \mathrm{~min}{ }^{-1}\right)$. The monosaccharides were detected with a post-column addition of base with $500 \mathrm{mM} \mathrm{NaOH}$ $\left(1 \mathrm{~mL} \mathrm{~min}{ }^{-1}\right)$. The relative proportion of each neutral monosaccharides was calculated based on the peak area, considering the sum of the peak areas of all monosaccharides as $100 \%$.

\section{Statistical analysis}

The data of the SPAD index (Chl- $a / b$ ratio), macro and micronutrients, and neutral monosaccharides profile were analyzed for normality (Shapiro-Wilk test) and, accordingly, were compared using the $F$ test, ANOVA and Pearson's parametric correlation test, considering significant when $p \leq 0.05$. The significant factors (nutrient concentration in the 'between-leaves' gradient and in the 'in-leaf' gradient) were represented in three-dimensional plots, according to leaf number and position of the blade leaf, using StatSoft version 10 [35]. The photosynthetic pigments content was analyzed with oneway ANOVA and Tukey's test $(p \leq 0.05)$, using the JMP software, version 5.0.1 (SAS Institute Inc.). The apparent nutrient remobilization of macro and micronutrients was calculated by dividing the difference between the average of +1 and +8 leaves by the average of the +1 leaf (i.e., non-senescent leaf), and nutrient accumulation percentage was obtained by dividing the difference between the average of +8 and +1 leaves by the average of +8 leaf. To evaluate which factors (SPAD index, macro and micronutrients concentration, and neutral monosaccharide content) were likely to be more relevant to the natural process of sugarcane leaf senescence, a principal component analysis (PCA) was performed comparing all collected data. Each matrix was previously tested for normality by Anderson-Darling test $(p<0.05)$, for homogeneity of variance by Levene's and Bartlett's tests, and for symmetry given by skewness value allowing a variation between -1 and +1 . A GLM test (General Linear Model) was performed to analyze if the level of the variation represented on the axes was related to senescence and the significance of each component.

\section{RNA isolation and real-time $\mathrm{qPCR}$ analysis}

The +1 (non-senescing) and +8 (senescing) leaves were harvested at three time points during the day: 0800, 1300, and $1800 \mathrm{~h}$. Harvested leaves were immediately frozen in liquid nitrogen and stored at $-80{ }^{\circ} \mathrm{C}$. RNA isolation was performed using TRIzol Reagent (Invitrogen Life Technologies), according to the manufacturer's recommendations. The purity/concentration was measured using a NanoDrop ND-1000 spectrophotometer (A260/280 and A260/230 ratios). The high-quality and DNA-free total RNA was used as template for cDNA synthesis using the ThermoScript ${ }^{\mathrm{TM}}$ RT-PCR System Kit (Invitrogen, Carlsbad, CA), according to manufacturer's instructions, and its concentration was diluted/adjusted in nuclease-free water and used for real-time PCR (RT-qPCR).

Four genes involved in cell-wall modification $[\alpha$-arabinofuranosidase $(\alpha-A R F), \alpha$-xylosidase $(\alpha-X Y L)$, $\beta$-glucosidase $(\beta$-GLU), and cellulase], and two involved in the leaf senescence [cysteine protease (SAG12-like) and xyloglucan endotransglucosylase (XET-like)] were selected to evaluate the expression profile of the targeted gene. The $S A G 12$-like and XET-like genes were identified in the sugarcane genome as orthologues of the SAG12 and XET of Arabidopsis thaliana [36, 37]. We decided to search for SAG12 candidates in the sugarcane EST database (SUCEST; [38]), using the Arabidopsis SAG12 gene as a query sequence. Subsequent BLAST analysis identified a region of high similarity between the Arabidopsis SAG12 gene and the putative sugarcane SAG12-like gene; this sequence was used for primer design to determine the expression pattern of the SAG12-like gene sugarcane senescing leaves. The same strategy was applied to the genes for the cell wall modification; however, the sequence was based on previously characterized genes in Sorghum bicolor, a monocot phylogenetically similar to sugarcane.

The primers (Additional file 1: Table S1) were designed using the PrimerQuest tool (Integrated DNA Technologies, Coralville, IA, USA). Relative expression was determined on a 7500 Fast Real-Time PCR System (Applied Biosystems), using SYBR green (SYBR Green qPCR Mix-UDG/ROX, Invitrogen), following the manufacturer's instructions. The relative quantification of the 
selected genes was determined by the $2^{-\Delta \Delta \mathrm{Ct}}$ comparative method [39]. The data were analyzed with the SDS 2.1 software (Applied Biosystems) and normalized using the expression profile of the glyceraldehyde-6-phosphate dehydrogenase (GAPDH) endogenous gene [40, 41]. All gene expression profile data were analyzed by one-way ANOVA and the means were compared using Tukey's test.

\section{Results}

\section{Determination of the harvesting period} and photosynthetic pigments content

Chloroplast degradation and subsequent loss of total chlorophyll are one of the earliest events during leaf senescence [28]. Therefore, the suitable harvesting period of sugarcane senescing and non-senescing leaves was determined by the analysis of total chlorophyll content throughout the plant life cycle using an SPAD meter. This method was chosen, because it is fast, accurate, and non-destructive. Measurements were taken in different leaves (between-leaves), named from +1 to +8 leaves, according to Kuijper numbering system (Fig. 1A), and in the different portions of the same leaf, named base, middle, and tip (in-leaf senescence gradient). During the eighth month, we observed a senescence gradient between +1 and +8 leaves, and also at different portions of the same leaf (Fig. 1B). Using the SPAD index to gauge senescence, we observed that the tip of the +8 leaf was the most senescent part of the tissue, while the base of the +1 leaf was the least senescent, indicating that in sugarcane, senescence proceeds from +8 to +1 leaves, and from the tip to the base of the leaf (Fig. 1C). Therefore, we decided to harvest leaf tissues for deeper analyses during the beginning of the eighth month of sugarcane growth.

For +1 and +8 leaves, the Chl- $a / b$ ratio and carotenoids (Cars) content were measured using the acetone extraction method. As expected, senescing leaves $(+8)$ presented the Chl- $a / b$ ratio two-fold lower, compared with non-senescing $(+1)$ leaves (Fig. 1D). These results are corroborated by the leaf yellowing observed in +8 leaves, while +1 leaves remained green at this stage (Fig. 1B). Similarly, Cars content decreased in senescing leaves (Fig. 1E), demonstrating a regular senescence pattern in sugarcane leaves.

\section{Nutrient remobilization and accumulation}

The content of nutrients in sugarcane cv. RB867515 measured using the +3 leaf followed the order $\mathrm{N}>\mathrm{K}>\mathrm{Ca}>\mathrm{Mg}=\mathrm{S}>\mathrm{P}$ for macronutrients, and $\mathrm{Fe}>\mathrm{Mn}>\mathrm{Zn}>\mathrm{Cu}>\mathrm{B}$ for micronutrients (Table 1).

The levels of leaf macro (N, P, K, Ca, Mg and S) and micronutrients $(\mathrm{Cu}, \mathrm{Zn}, \mathrm{Fe}, \mathrm{Mn}$ and $\mathrm{B})$ were analyzed
Table 1 Estimated demand of macro and micronutrients in sugarcane index leaf cv. RB867515

\begin{tabular}{lclc}
\hline Macronutrients (g kg & dry mass) & $\begin{array}{l}\text { Micronutrients } \mathbf{~} \mathbf{m g ~ k g}^{\mathbf{- 1}} \mathbf{d r y} \\
\text { mass) }\end{array}$ \\
\hline Nitrogen & $14.0( \pm 1.1)^{\mathrm{a}}$ & Iron & $132.7( \pm 15.1)$ \\
Potassium & $10.9( \pm 0.7)$ & Manganese & $54.0( \pm 13.6)$ \\
Calcium & $4.6( \pm 1.3)$ & Zinc & $11.0( \pm 1.3)$ \\
Magnesium & $2.4( \pm 0.1)$ & Copper & $4.6( \pm 0.8)$ \\
Sulfur & $2.2( \pm 0.3)$ & Boron & $2.9( \pm 0.2)$ \\
Phosphorus & $1.4( \pm 0.1)$ & & \\
\hline
\end{tabular}

a Values of each nutrient are presented as mean \pm standard deviation (three biological replicates, each composed of $a+3$ leaf pool of the 5 plants)

comparing leaves at different stages of senescence ('between-leaves' comparison) and different portions ('in-leaf' comparison) of sugarcane leaves. Threedimensional plots showing the levels of macro (Fig. 2) and micronutrients (Fig. 3) showed significant differences between-leaves at different senescence stages ('between-leaves' gradient) which were observed for all nutrients. For the different parts of the leaf ('in-leaf' gradient), differences were observed for all nutrients with the exception of $\mathrm{N}, \mathrm{Mg}, \mathrm{Zn}$, and $\mathrm{Al}$. These results were corroborated by variance analysis of the macro and micronutrients, which demonstrated the significant differences in the 'between-leaves' $(+1$ to +8$)$ and the 'inleaf' (base, middle, tip portions) senescence gradients (Additional file 2). These data indicated either a high mobility or accumulation of these nutrients in sugarcane leaves.

The nutrients remobilized during sugarcane leaf senescence are presented in Fig. 4a. N, P, and $\mathrm{K}$ were the nutrients that had the highest levels of remobilization, with values of 55,65 , and $70 \%$ of remobilization, respectively. $\mathrm{B}, \mathrm{Cu}, \mathrm{Fe}$, and $\mathrm{Zn}$ were also remobilized during leaf senescence, displaying levels of remobilization ranging from 20 to $40 \%$. In addition, the different portions of the leaf (base, middle, and tip) displayed different patterns of remobilization, with $\mathrm{B}, \mathrm{Fe}$, and $\mathrm{Zn}$ being remobilized mostly from the tip of the leaf, while $\mathrm{P}$ and $\mathrm{K}$ presented high levels of remobilization mostly from the leaf base. Interestingly, B was remobilized only from the tip and the middle of the leaf blade (Fig. 4a).

The nutrients $\mathrm{Ca}, \mathrm{S}, \mathrm{Mg}, \mathrm{B}, \mathrm{Mn}$, and $\mathrm{Al}$ showed an accumulation pattern in sugarcane senescing leaves (Fig. 4b). $\mathrm{Ca}, \mathrm{S}, \mathrm{Mn}$, and $\mathrm{Al}$ were accumulated in relatively higher proportions in the leaves. $\mathrm{Ca}$ and $\mathrm{Al}$ had distinct levels of accumulation in the different portions of the leaf, with levels ranging from 50 to $75 \%$ of accumulation from the tip to the leaf base. $\mathrm{Mg}$ and B showed moderate $(25 \%$ in average) levels of accumulation. It is also interesting to note that $\mathrm{Mg}$ also showed high levels of accumulation in 


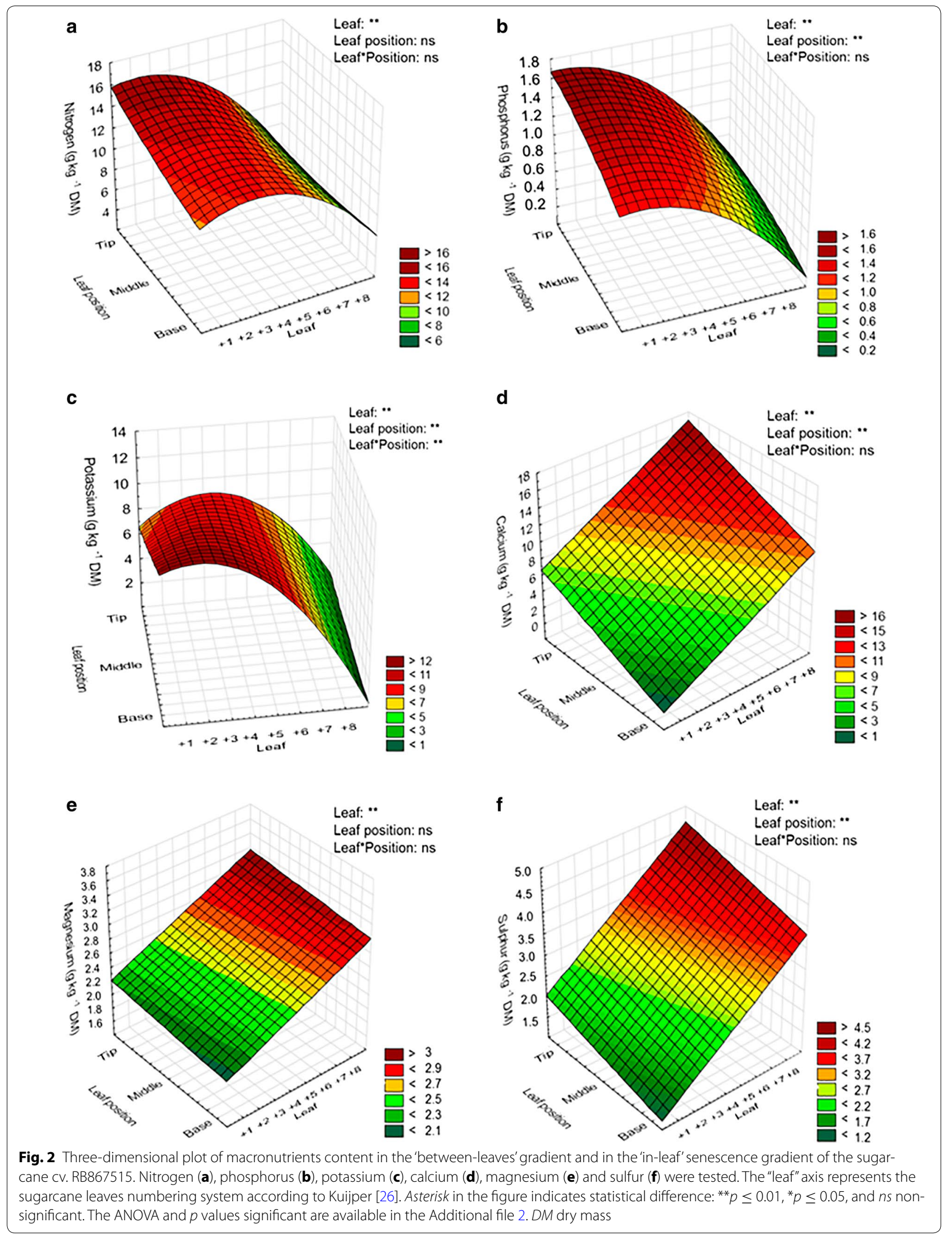




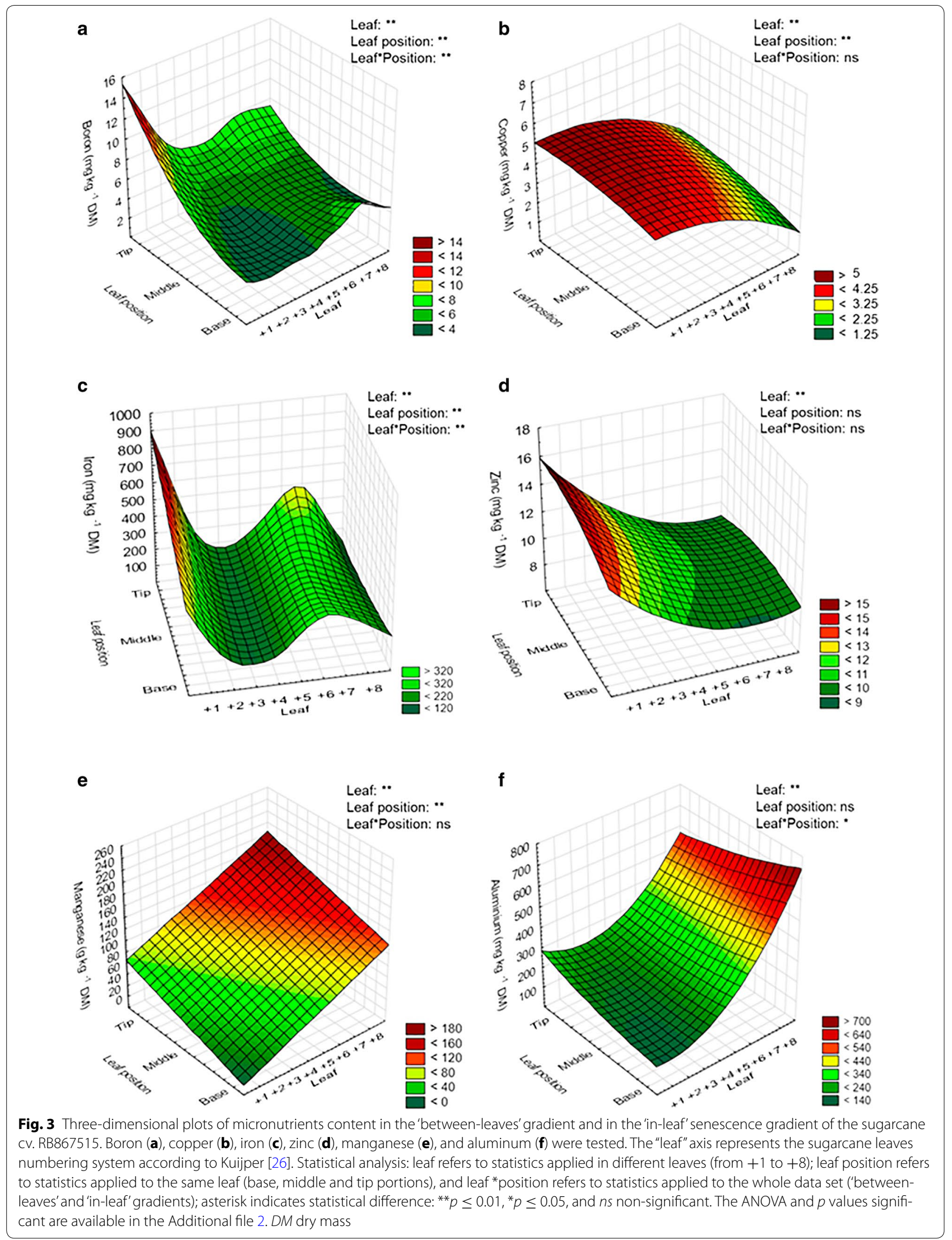




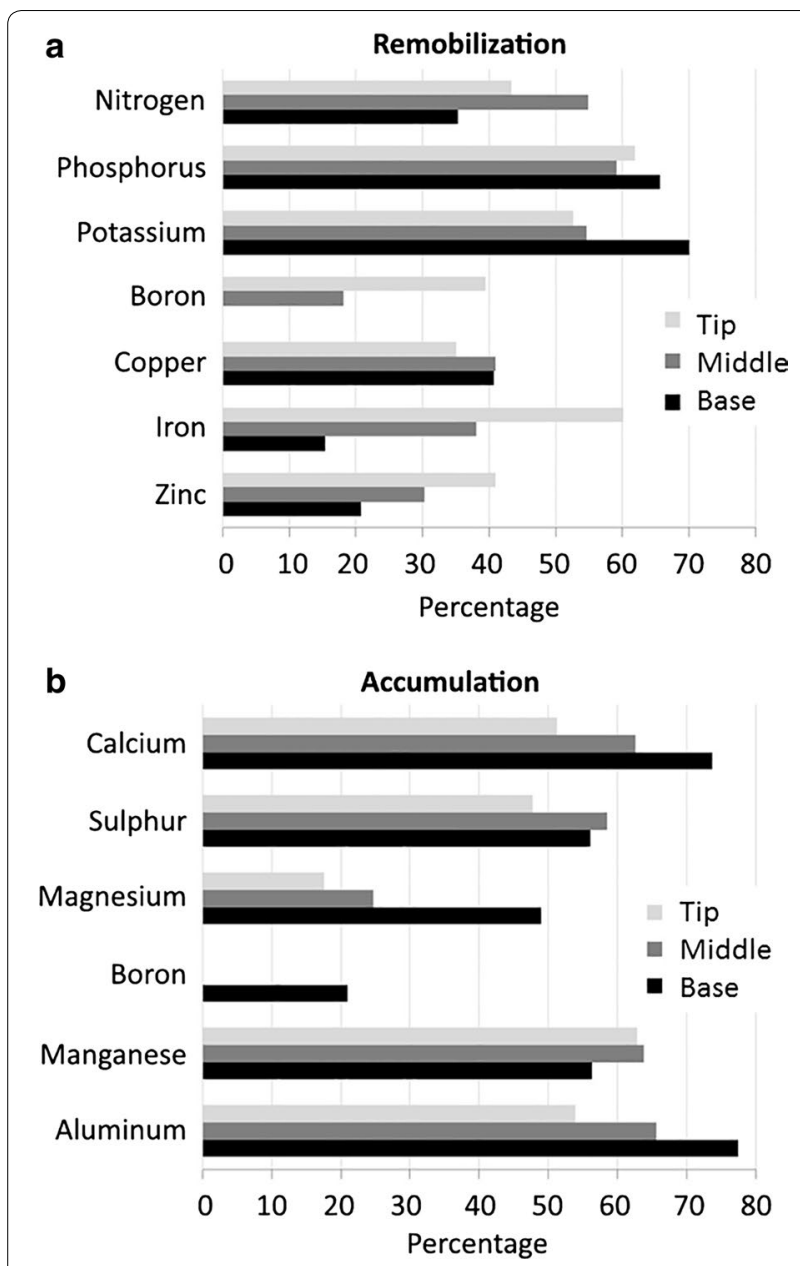

Fig. 4 Apparent nutrient remobilization (a) and accumulation (b) of nutrients during senescence of leaves of the sugarcane cV. RB867515. The nutrient reduction percentage was calculated dividing the difference between the +1 and +8 leaves by +1 leaf. In contrast, the nutrients accumulation percentage was obtained by dividing the difference between the +1 and +8 leaves by +8 leaf

the leaf base, approximately two-fold compared to the other portions of the leaf (Fig. 4b).

The percentages of remobilization or accumulation of nutrients in sugarcane leaves followed the order $\mathrm{P}>\mathrm{K}>\mathrm{N}>\mathrm{Cu}>\mathrm{Fe}>\mathrm{Zn}>\mathrm{B}$ and $\mathrm{Ca}=\mathrm{Al}>\mathrm{Mn}>\mathrm{S}>\mathrm{Mg}>\mathrm{B}$, respectively. The Pearson's correlation matrix between SPAD index and macro and micronutrients contents at the base, middle, or tip positions of the leaf is presented in the Additional file 3. A positive correlation between SPAD index, representing total chlorophyll levels, with remobilized nutrients $(\mathrm{N}$, $\mathrm{P}, \mathrm{K}, \mathrm{Cu}$, and $\mathrm{Zn}$ ) was observed, in contrast with a negative correlation with the accumulated (non-remobilized) nutrients $(\mathrm{Ca}, \mathrm{S}, \mathrm{Mg}, \mathrm{Mn}$, and $\mathrm{Al})$. These data represent the pattern of leaf yellowing (Fig. 1B), reduction of the content of the photosynthetic pigments (Chl- $a / b$ and Cars) (Fig. 1C, D), and the remobilization/accumulation of macro and micronutrients (Figs. 2, 3) triggered by the natural senescence process in sugarcane cv. RB867515.

\section{Neutral monosaccharides profile}

The neutral monosaccharides fucose (Fuc), rhamnose (Rha), arabinose (Ara), galactose (Gal), glucose (Glc), and xylose $(\mathrm{Xyl})$ were analyzed from +1 to +8 leaves. Threedimensional plots were used to represent the levels of these monosaccharides 'between-leaves' and 'in-leaf' senescence gradients (Fig. 5). Ara and Xyl are monosaccharides released from arabinoxylan, one of the most abundant hemicelluloses in sugarcane cell walls [33]. Both monosaccharides showed no significant differences 'between-leaves' and 'in-leaf' senescence gradients (Fig. 5c, f), suggesting that arabinoxylan is not degraded in the senescence process. As we used TFA for hydrolysis, we do not expect Glc to come from cellulose. Thus, it is very likely that the detected Glc in sugarcane leaves (Fig. 5e) is derived from the mixed linkage $\beta$-glucan ( $\beta$-glucan), another hemicellulose found in sugarcane cell walls [33]. However, steps to eliminate starch from the cell-wall preparation were not carried out; therefore, starch may also contribute to Glc. In addition, there is a possibility that a minor portion of the Glc and Xyl would come from xyloglucan that also occurs in sugarcane leaf cell walls may not be discarded [33]. A small percentage ( $2.5 \%)$ of Gal, and only traces of Fuc and Rha were detected. In these cases, we assumed that these monosaccharides (in addition to some of the arabinose mentioned above) are derived from pectin polymers. Our results indicate that no significant changes in major hemicellulose or pectin cell-wall polymers occur during sugarcane leaf senescence.

Co-variance analysis demonstrated that in the 'in-leaf' senescence gradient, the monosaccharides Rha, Ara, Gal, and Glc are positively correlated, while Xyl correlates negatively to all monosaccharides listed above (Additional file3). According to the Pearson's correlation matrix between total chlorophyll content (SPAD index), macro and micronutrients levels, and the neutral monosaccharide profile, it was observed that, in general, the sugars correlate only among them, but never with nutrients or senescence (Additional file 3). These results suggest a non-dependent relationship between the composition of the cell wall and total chlorophyll content or nutrient composition during sugarcane leaf senescence. In addition, a principal component analysis (PCA) considering the three parameters mentioned above was performed to analyze the base, middle, and tip portions of the sugarcane leaf blade (Fig. 6). It was noticed that the main differences between senescing and non-senescing 

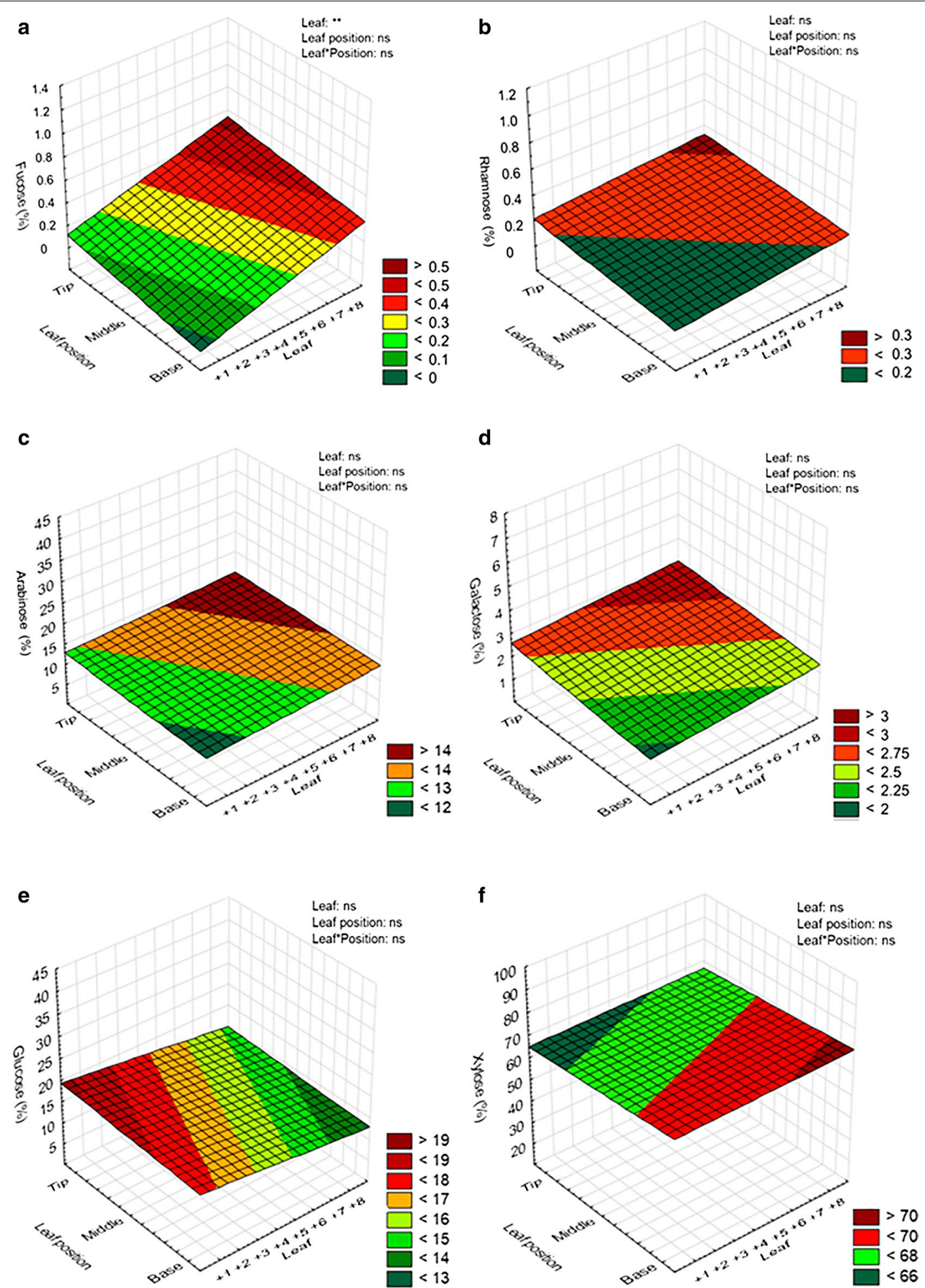

Fig. 5 Profile of the neutral monosaccharides fucose $(\mathbf{a})$, rhamnose $(\mathbf{b})$, arabinose $(\mathbf{c})$, galactose $(\mathbf{d})$, glucose (e), and xylose (f) in the 'betweenleaves' gradient and in the 'in-leaf' senescence gradient of the sugarcane cv. RB867515. The "leaf" axis shows the sugarcane leaf number according to Kuijper [26]. The amounts of all neutral monosaccharides correspond to $100 \%$ of the cell-wall major components. Statistical analysis: leaf refers to statistics applied in different leaves (from +1 to +8 ); leaf position refers to statistics applied to the same leaf (base, middle, and tip portions) and leaf* position refers to statistics applied for the whole data set ('between-leaves' and 'in-leaf' gradients); asterisk indicates statistical difference: ${ }^{* *} p \leq 0.01,{ }^{*} p \leq 0.05$, and $n s$ non-significant 
leaves are in the total chlorophyll content (SPAD index) and nutrient remobilization/accumulation, and not in monosaccharides levels, supporting the idea that cell wall does not change significantly during sugarcane leaf senescence in cv. RB867515.

\section{Expression profile of genes involved in cell-wall modification and leaf senescence}

To evaluate whether subtle changes in cell walls might have occurred during senescence, the expression of the cell wall-associated genes $\alpha$-arabinofuranosidase, $\alpha$-xylosidase, $\beta$-glucosidase, and cellulase was followed throughout the day $(08: 00-18: 00 \mathrm{~h})$ in +1 and +8 leaves (Fig. 7). The expression of $\beta$-glucosidase (Fig. 7c) in senescing leaves was lower when compared to nonsenescing leaves in the early morning $(08: 00 \mathrm{~h})$, while the expression of $\alpha$-xylosidase was lower in +8 leaves at 13:00 $\mathrm{h}$ and at 18:00 h (Fig. 7b). Cellulase (Fig. 7d) and $\alpha$-arabinofuranosidase (Fig. 7a) expression levels did not significantly change between +1 and +8 leaves during the time period analyzed.

In addition to the cell wall-related genes, we have measured the expression levels of two senescence-related genes: senescence-associated gene 12-like (SAG12-like), and xyloglucan endotransglucosylase-like (XET-like). The SAG12-like gene expression was higher in senescing leaves in all time points analyzed, with levels that were 5.5-fold higher when compared to non-senescing leaves (Fig. 7e). The XET-like expression was significantly higher in +8 leaves, when compared to +1 leaves, at 13:00 h (Fig. 7f).

Overall, the expression of some genes related to cellwall modification suggests a complex regulation of these genes in sugarcane leaves. In addition, senescence-associated genes in sugarcane showed a high level of expression in senescing leaves, and therefore, their promoters are candidates for biotechnological applications aimed at delaying or accelerating senescence in sugarcane.

\section{Discussion}

The first step for 2G-bioethanol production is the hydrolysis of the lignocellulosic material, a task that is not simple to achieve, mainly because of the plant cell-wall recalcitrance. Sugarcane is among the most suitable crops for 2G-bioethanol production. This crop accumulates high contents of sucrose in its culms, which is fermented into bioethanol by yeasts (1G-bioethanol). The remaining biomass from this process composed of sugarcane bagasse, straw, and senescing leaves is considered waste by the sugarcane industry, but may be used for 2G-bioethanol production $[1,4,42,43]$. The understanding of the natural senescence process and its relationship with cell-wall modification can provide useful information to facilitate
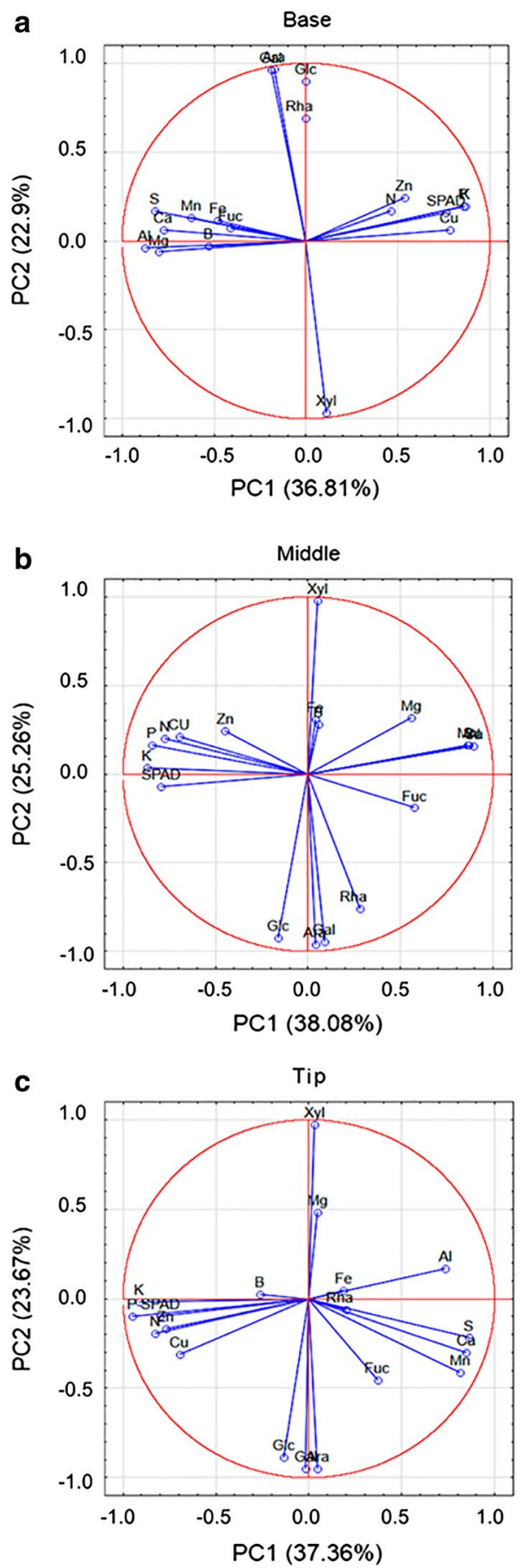

Fig. 6 Biplot graphics of the principal component analysis (PCA) from SPAD index, macro and micronutrients, and neutral monosaccharides from base (a), middle (b), and tip (c) portions of the leaf blade. Each point integrates all components evaluated related to sugarcane leaf senescence. Values in brackets show the percentage of the variance explained by each axis. SPAD SPAD index, $N$ nitrogen, $P$ phosphorous, K potassium, Ca calcium, Mg magnesium, $S$ sulfur, $B$ boron, Cu copper, Fe iron, Zn zinc, Mn manganese, Al aluminum, Fuc fucose, Rha Rhamnose, Ara arabinose, Gal galactose, Glc glucose, Xyl xylose 

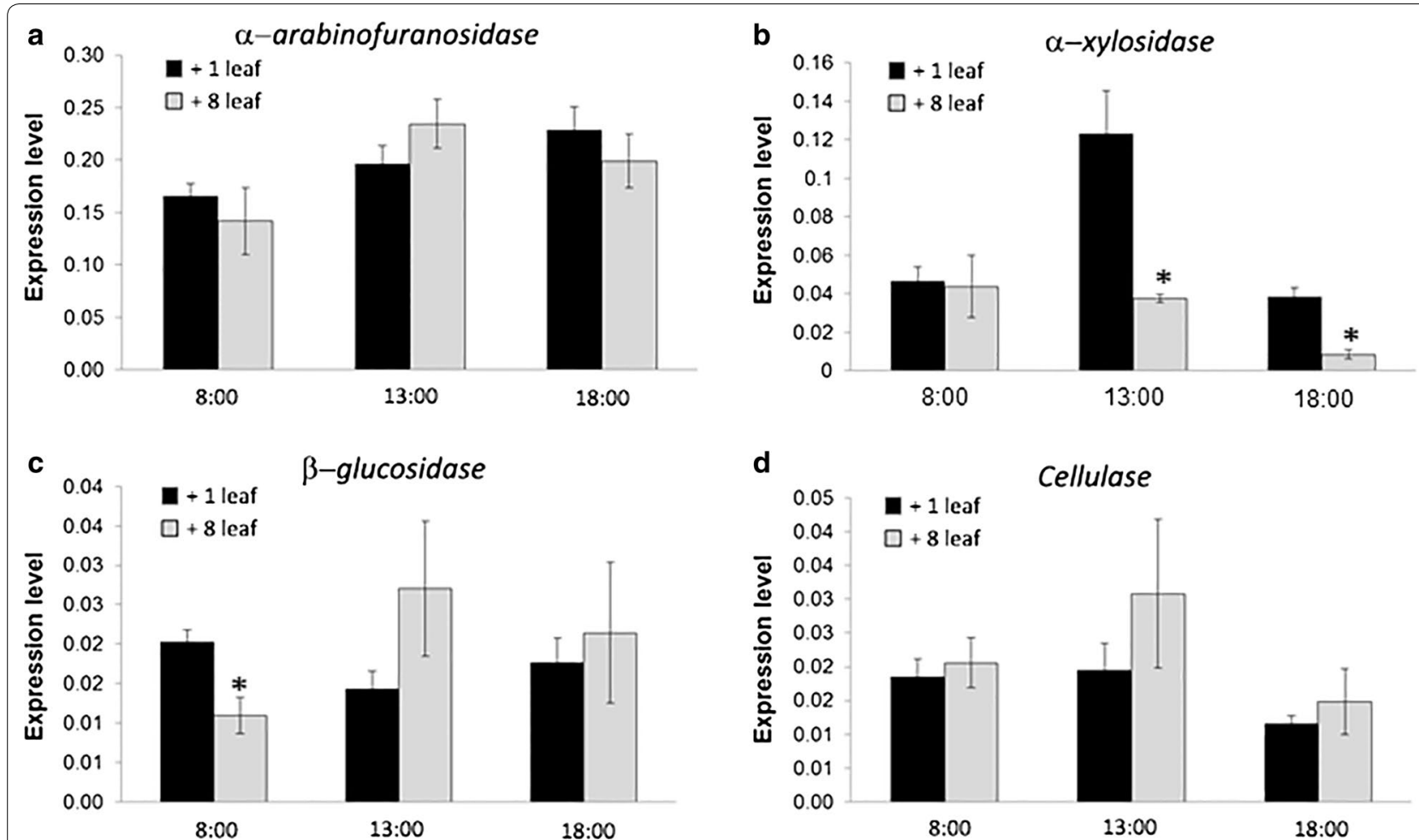

d
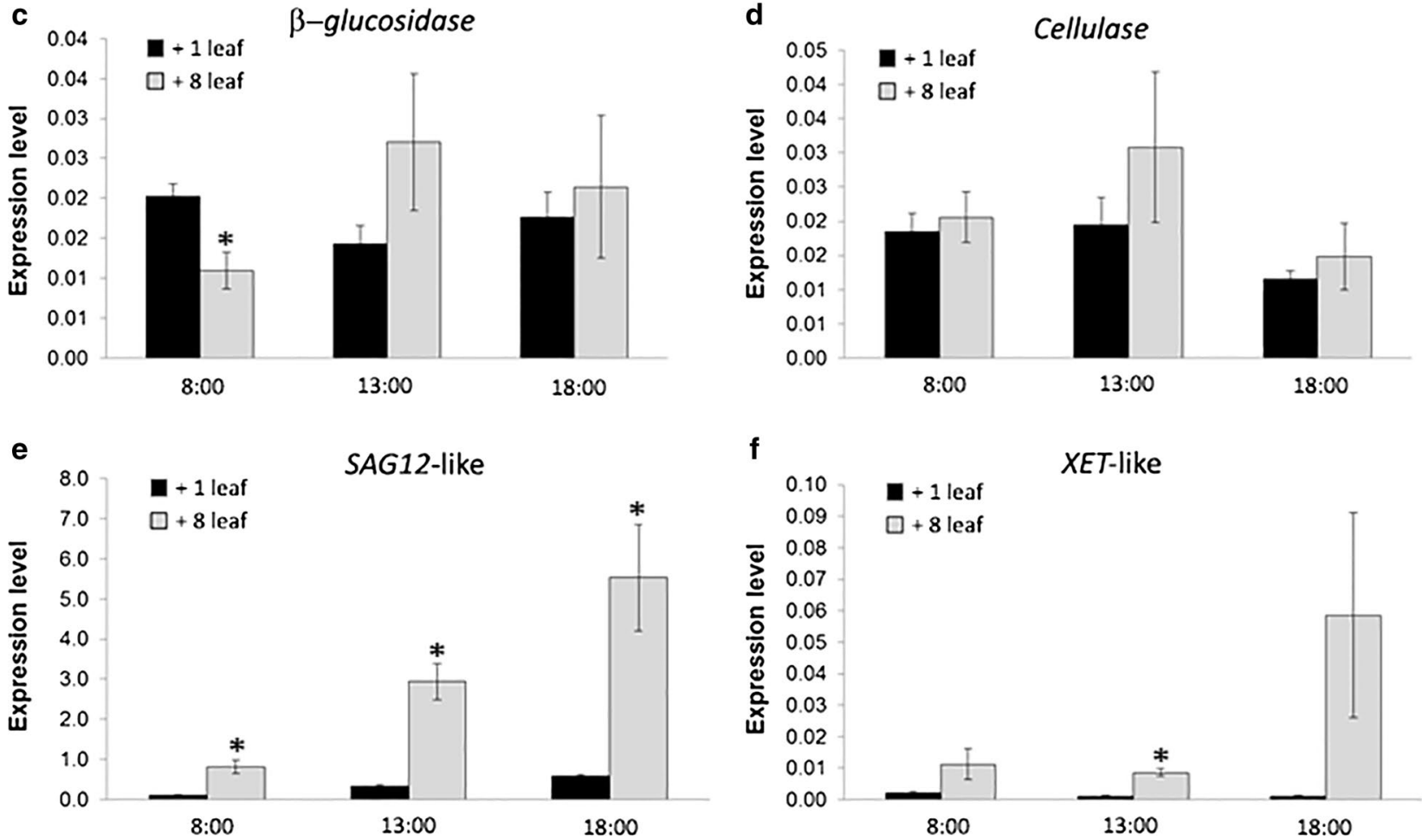

f

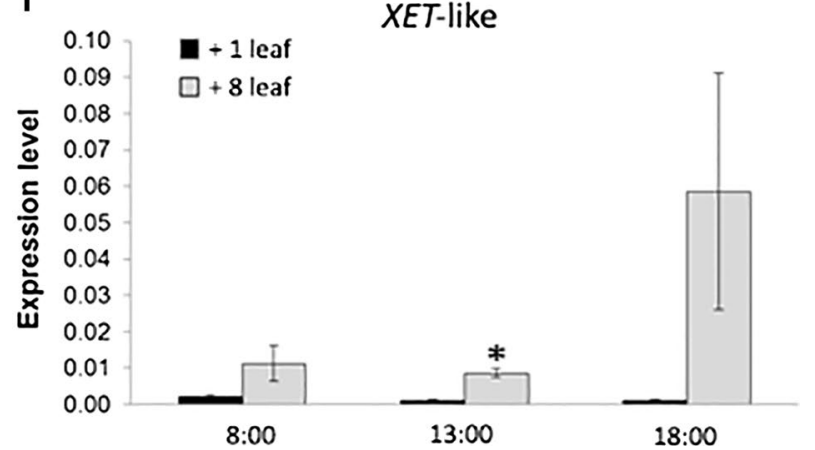

Fig. 7 Relative expression of the a-arabinofuranosidase (a), a-xylosidase (b), $\beta$-glucosidase (c), cellulase (d), SAG12-like (e), and XET-like (f) genes in non-senescing $(+1$, black bars) and senescing $(+8$, grey bars) leaves of the sugarcane $\mathrm{cV}$. RB867515. The data were collected at time points from 08:00 to 18:00 h. The GAPDH endogenous gene expression was used as reference to measure relative expression levels, which were calculated according to [39]. The asterisks indicate statistical significance at $p \leq 0.05$ when +1 leaves were compared to +8 leaves. Vertical bars show \pm S.E. for $n=3$

2G-bioethanol generation from sugarcane leaves. In this work, experiments were carried out with a sugarcane commercial variety (RB867515) in field conditions to depict some events occurring during leaf senescence.

\section{Sugarcane leaf senescence is characterized by strong reduction in photosynthetic pigment content}

The sugarcane leaf senescence process corresponds to the last stage in its development, which is governed by developmental aging and influenced by several environmental and endogenous signals, ultimately resulting in programmed cell death [44]. The earliest events during senescence are characterized by chloroplast degradation, loss of Chl- $a / b$, and other macromolecules, several changes in cellular metabolism and in gene expression profiles [21, 22, 45]. Chloroplast degradation is usually followed by nutrient remobilization from senescing leaves to other developing organs $[27,28]$. Our results demonstrated that photosynthetic pigments content decreased in sugarcane senescing leaves, correlating with the leaf yellowing gradient (Fig. 1). 
Chloroplasts are not only essential to photosynthesis, but are an important cellular component for nitrogen $(\mathrm{N})$ storage during leaf expansion [46]. The disassembly of the chloroplasts during leaf senescence releases some nutrients, mainly $\mathrm{N}$, which is mobilized to the sink organs, flowers, and seeds [21]. The optimal utilization of nutrients accumulated during the photosynthetic period is critical for plant fitness, which is critically affected by fine control of leaf senescence process to ensure its effective remobilization [22]. In several higher plant species, leaf senescence progresses from the tip towards to the base portion of the leaf blade [22], indicating nutrient outflow direction [46]. Our results demonstrated that the characteristic senescence pattern observed in other plant species also occurs in sugarcane senescing leaves (Figs. 1, 2, 3).

\section{Not all nutrients are remobilized during sugarcane leaf senescence}

The estimated required nutrients for sugarcane cv. RB867515 (Table 1) predicts that the most required macronutrient for this cultivar is $\mathrm{N}$ (14.04 $\mathrm{g} \mathrm{kg}^{-1}$ dry mass), followed by K (10.87 $\mathrm{g} \mathrm{kg}^{-1}$ dry mass). Sugarcane $\mathrm{N}$ uptake depends on different factors, such as soil, climate, genotype, and biomass accumulation pattern [47]. For instance, sugarcane plants grown in different regions of Australia and Hawaii have higher demand for $\mathrm{K}$ than for $\mathrm{N}$ [48]. The sugarcane cv. RB867515 is a high-yielding crop, also accumulating high levels of sucrose and biomass, and, therefore, requires a large amount of nitrogen to achieve its highest productivity, suggesting that the requirement for this nutrient is higher in cv. RB867515 than in the Australian and Hawaiian crops mentioned above. Concerning the micronutrients, $\mathrm{Fe}$ is the most required (132.67 $\mathrm{mg} \mathrm{kg}^{-1}$ dry mass), followed by $\mathrm{Mn}$ (54 $\mathrm{mg} \mathrm{kg}^{-1}$ dry mass).

The nutrients remobilized in sugarcane senescing leaves were $\mathrm{N}, \mathrm{P}, \mathrm{K}, \mathrm{B}, \mathrm{Cu}, \mathrm{Fe}$, and $\mathrm{Zn}$, while $\mathrm{Ca}, \mathrm{S}, \mathrm{Mg}$, $\mathrm{B}, \mathrm{Mn}$, and $\mathrm{Al}$ were accumulated (Fig. 4). The levels of $\mathrm{N}$ remobilization were higher at the tip and the middle of the leaf blade, the portions where senescence is more pronounced. These results are expected, since most of the $\mathrm{N}$ is remobilized from the chloroplast degradation, and this process is also accelerated at the tip and the middle portions of the leaf. The remobilization of $\mathrm{P}$ was homogenous throughout the leaf, while $\mathrm{K}$ showed higher levels of remobilization in the leaf base. In wheat, it was demonstrated that $\mathrm{P}$ and $\mathrm{K}$ declined rapidly in the oldest leaf, even prior to senescence [49]. Interestingly, the highly mobile nutrients $\mathrm{S}$ and $\mathrm{Mg}$ were not remobilized in sugarcane senescing leaves. As discussed by Argenta et al. [27], differently from $\mathrm{N}$, the nutrients $\mathrm{S}$ and $\mathrm{Mg}$ are stored in the vacuoles under inorganic forms, and their mobilization may be senescence-independent.
Our results provide additional argument to this discussion, since the highly mobile nutrients $\mathrm{S}$ and $\mathrm{Mg}$ showed a small accumulation in sugarcane senescing leaves, instead of remobilized.

$\mathrm{Ca}, \mathrm{Al}$, and $\mathrm{Mn}$ were not remobilized at high levels in sugarcane senescing leaves (Fig. 4b). These results are expected, because these nutrients are considered immobile in the phloem. Accordingly, Hill and Lonargan [49] showed that $\mathrm{Ca}$ and $\mathrm{Mn}$ increased during the life cycle of the oldest leaf of wheat and did not decline during senescence. It is known that $\mathrm{Al}$ can affect $\mathrm{Ca}$ absorption from the soil due to competition or blocking of the channels responsible for $\mathrm{Ca}$ transport [50]. Our results showed that the accumulation levels of $\mathrm{Ca}$ and $\mathrm{Al}$ followed the same pattern throughout the leaf portions, suggesting that $\mathrm{Al}$ could be interfering with $\mathrm{Ca}$ absorption. However, because $\mathrm{Ca}$ contents in the +3 leaves were considered normal (4.6 $\mathrm{g} \mathrm{kg}^{-1}$, Table 1), one can speculate that, in fact, Al did not affect the absorption of $\mathrm{Ca}$ under the conditions used in our experiment, but it can be absorbed from the soil at similar rates of $\mathrm{Ca}$ in the sugarcane cultivar studied.

$\mathrm{Cu}, \mathrm{Fe}, \mathrm{Zn}$, and $\mathrm{B}$ were all remobilized in sugarcane senescing leaves. Our data suggest that B might be remobilized only from the tip and middle portions of the leaf, while it was not remobilized in the base. The remobilization of these micronutrients under leaf senescence should be interpreted with caution, since the remobilization could be strongly affected by nutrient deficiency [27]. However, the contents of these nutrients in our experimental conditions were above the critical levels for this crop [47, 51, 52], as demonstrated by cv. RB867515 nutrient leaf index (Table 1). Therefore, it can be suggested that $\mathrm{Cu}, \mathrm{Fe}, \mathrm{Zn}$, and $\mathrm{B}$ are being remobilized in a senescence-dependent manner, and not because of these nutrients deficiency. Our results highlight the intense dynamics of nutrient remobilization in senescing leaves of sugarcane, and these data can be further used to demonstrate the correlations between senescence timing, nutrient-use efficiency, and productivity in this crop [23, 53-57].

\section{Cell walls are not degraded during sugarcane leaf senescence}

Despite the fact that if leaves remained in the field they could return some nutrients back into soil, senescing leaves, given nutrient remobilization, may be better used as feedstock for bioethanol production after suitable pretreatments [58]. One concern about this strategy is the possibility that the plant cell wall could be modified during senescence in ways that deconstruction of senescing plant cell walls would be more difficult. Therefore, here, we aimed at analyzing the neutral monosaccharide 
profile of sugarcane senescing leaves to evaluate whether substantial changes in-leaf cell wall could occur.

Since no major differences were observed in sugarcane cell walls during the senescence, our results confirm that leaves can be used as feedstock for biofuel production using pretreatments established for non-senescing leaves, without additional efforts. This is extremely important, because currently, at raw sugarcane cutting, 12-20 tons $/ \mathrm{ha}^{-1}$ of biomass is left on the soil surface, not being used for energy production [59]. About $70 \%$ of this biomass can be used for lignocellulosic ethanol, electricity, and heat production, reducing waste and increasing profits. Moreover, cell-wall composition in leaves of the cv. RB867515 evaluated by monosaccharide analysis (Fig. 5) corroborates the results observed for the cultivar SP80-3280 [33]. This suggests that cell-wall composition does not vary among sugarcane cultivars, facilitating the 2G-bioethanol industrial processing, since little adaptation might be necessary for industrial processing of different varieties.

\section{Senescence-related genes are strongly expressed during sugarcane leaf senescence and expression levels of cell wall-related genes undergo small changes}

Leaf senescence is a well-studied phenomenon in some plant species, especially in Arabidopsis thaliana, where molecular and genetic studies have advanced in the past years. Many studies demonstrated that senescenceassociated genes (SAGs) are involved in Arabidopsis leaf senescence [37, 60-63]. However, a remarkably low number of cell wall-related genes have been reported to be associated to senescence. This corroborates our findings that cell walls undergo very little or no changes during leaf senescence.

Regarding other classes of genes, SAG12, specific SAG present in Arabidopsis, encodes a cysteine protease and has high levels of expression during aging and fast response to external factors that accelerate the aging process [64]. The $S A G 12$ promoter is active when fused to other exogenous genes $[61,65]$, allowing the target gene transcription specifically during the senescence process. In this work, we were able to find in the sugarcane genome a gene containing a sequence similar to the Arabidopsis SAG12, named SAG12-like. As expected, our results demonstrated that sugarcane $S A G 12$-like was highly expressed in senescing leaves, demonstrating the presence of this senescence-marker gene in the complex sugarcane genome (Fig. 7e).

Park et al. [36] characterized the expression of four genes during leaf senescence in Arabidopsis. One of these genes, SEN4, was strongly up-regulated under senescence initiated by several factors and its sequence was similar to $\mathrm{TCH} 4$, an Arabidopsis gene encoding a xyloglucan endotransglucosylase (XET), currently designated xyloglucan end-Transglycosylase Hydrolase (XTH). XTHs belong to a class of enzymes responsible for complex modifications in xyloglucan molecules being related to its hydrolysis as well as to xyloglucan structure rearrangement through transglycosylation [66]. There seems to exist multiple genes that encode XTHs in sugarcane [67], but their specific functions are unknown. We have chosen to work with $X T H$ not only because of its possible involvement in the senescence process, but also because it is related with cell-wall modification, one of the objectives of this study. In fact, the sugarcane $X T H$ was upregulated in +8 leaves (senescing), compared with +1 leaves (non-senescent) in a time-dependent manner. In barley, an endotransglucosylase/hydrolase gene was also found to be highly expressed in senescing leaves of field grown plants [68], reinforcing that $X T H$-like genes could be involved during the senescence process in monocots. Thus, the high differential expression of $X T H$ in sugarcane leaves during senescence might mean that xyloglucan (a minor component of sugarcane walls according to Eklöf et al. [66]) could be attacked during senescence. However, here, we did not look into xyloglucan fine structure to determine whether such fine structural changes really occur.

Previous studies have been shown a variety of genes involved in the senescence process in other monocots, such as wheat $[69,70]$ and barley $[68,71-73]$. Kajimura et al. [69] identified two SAG genes in wheat, namely TaSAG5 and TaSAG6, which increased in a time-course manner in the flag leaf and seeds, and, therefore, suggested as molecular markers to evaluate the degree of wheat flag senescence and seed maturation. Gregersen and Holm [70] performed a very comprehensive analysis of the gene expression networks involved in the senescence process in wheat. They found that many genes responsible for the senescence process in wheat overlapped with genes considered to be involved in senescence in other species, but considerable differences were also observed. In addition, it was verified that in wheat, a number of regulatory genes were up-regulated under senescence, especially members of the NAC-domain and WRKY transcription factors. In barley, Parrot et al. [71] applied a steam-girdling protocol in leaves to uncover the gene expression of this monocot plant under senescence. The study demonstrated that many genes for proteases (aminopeptidases, plastidial aspartyl peptidase cnd41, vacuolar thiol and serine proteases, and carboxypeptidase $\mathrm{cp}$-mIII) were differentially expressed, in addition to hexokinases and SAG-12. A remarkable gene family that is co-regulated with senescence-associated genes belongs to the NAC transcription factor gene family. Christiansen and Gregersen [68] performed a screening of available 
promoter sequences of barley genes containing DNAbinding motifs for NAC transcription factors, and they found that genes up-regulated during senescence demonstrated a significant representation of these motifs, suggesting regulation of senescence-associated genes by the NAC transcription factors. In addition, this study showed that genes containing the motifs in their promoters were usually highly co-expressed with members of the NAC gene family. Members of the NAC transcription factor gene family were also found in senescing leaves during a transcriptomic study in barley grown in the field supplemented with standard or high nitrogen supply. A detailed characterization of the gene networks involved in the sugarcane senescence process is far beyond of the present work purposes. However, based on the studies mentioned above, a comprehensive gene expression analysis during the leaf senescence process are currently being conducted by our group not only in sugarcane, but also in Setaria viridis, an emerging model for genetic studies in $\mathrm{C} 4$ plants.

In addition to the neutral monosaccharide analysis, we also characterized expression levels of selected cell wallrelated genes. Based on the sugarcane cell-wall composition, we chose four cell wall-related genes encoding an $\alpha$-arabinofuranosidase, an $\alpha$-xylosidase, a $\beta$-glucosidase, and a cellulase. The expression of these genes was monitored throughout the day $(08: 00-18: 00 \mathrm{~h})$ in nonsenescing $(+1)$ and senescing $(+8)$ leaves. Diurnal oscillations in the expression levels are shown in Fig. 7a-d.

Circadian responses of cell wall-related genes are described in the literature $[74,75]$, although more detailed studies on how these oscillations affect cell-wall dynamics are needed. The $\alpha$-arabinofuranosidase and cellulase genes did not significantly change their expression levels when +1 leaves were compared to +8 leaves throughout the day, whereas senescing leaves had decreased levels of $\alpha$-xylosidase and $\beta$-glucosidase expression at specific time points. These small changes in cell wall-related gene expression levels reinforce the assumption that the cell wall is not drastically modified under senescence. However, due to the differences observed for $\alpha$-xylosidase and $\beta$-glucosidase expressions between +1 and +8 leaves at specific time points, it cannot be excluded that subtle changes in the cell wall is occurring during the senescence process, but not detected in our analyses due to technical limitations. Therefore, further investigations using more sensitive sugar analysis techniques are needed to shed light on these issues.

\section{Conclusions}

Natural leaf senescence of the sugarcane cv. RB867515 is characterized by significant reduction in photosynthetic pigments content, nutrient remobilization of $\mathrm{N}, \mathrm{P}, \mathrm{K}, \mathrm{B}$, $\mathrm{Cu}, \mathrm{Fe}$, and $\mathrm{Zn}$, but not of $\mathrm{Ca}, \mathrm{S}, \mathrm{Mg}, \mathrm{B}, \mathrm{Mn}$ and $\mathrm{Al}$. Our study on nutrient remobilization under senescence in a vigorous sugarcane cultivar can contribute to the understanding on how nutrient balance in a high-yielding crop is achieved. In general, neutral monosaccharide profile did not change significantly with leaf senescence, suggesting that sugarcane senescing leaves can be used as feedstock for biofuel production using pretreatments established for non-senescing leaves without additional efforts. In addition, the XET-like or SAG12-like promoters may be used to drive the expression of other stress-related genes or genes involved in cell-wall deconstruction at the onset of the senescence process. Specifically, these promoters could be used to drive the expression of genes related to cell wallmodifying enzymes to produce cell-wall modifications for the harvesting period, facilitating the pretreatments for biomass hydrolysis and the production of 2G-bioethanol.

\section{Additional files}

Additional file 1. Primers used in this study.

Additional file 2. Analysis of variance (ANOVA) of the (A) SPAD index, (B) macronutrients, (C) micronutrients, and (D) neutral monosaccharides. The significant data were highlighted in red.

Additional file 3. Correlation matrix between macronutrients, micronutrients, SPAD index, and neutral monosaccharides into in-leaf senescence gradient. $(\mathbf{A})$ base, $(\mathbf{B})$ middle, and $(\mathbf{C})$ tip portions of the leaf blade. Significant correlation data (Pearson's correlation matrix) were highlighted in red ( $p$ value $\leq 0.05$ )

\section{Abbreviations}

2G: second generation; SAG: senescence-associated gene; XET: xyloglucan endotransglucosylase; PCD: programmed cell death; Cars: carotenoids; TFA: trifluoroacetic acid; PCA: principal component analysis; GLM: general linear model; $\alpha$-ARF: $a$-arabinofuranosidase; $\alpha$-XYL: $a$-xylosidase; $\beta-G L U$ : $\beta$-glucosidase; GAPDH: glyceraldehyde-6-phosphate dehydrogenase; Fuc: fucose; Rha: rhamnose; Ara: arabinose; Gal: galactose; Glc: glucose; Xyl: xylose.

\section{Authors' contributions}

$\mathrm{HBCM}, \mathrm{BFQ}$, and MSB conceived and designed the experiments. MTBM, PKM, and WRS performed the gene expression analysis and wrote the manuscript draft. PAO, MSB, APS, and AKK designed the carbohydrate analysis assays, analyzed the carbohydrate characterization data, and wrote the manuscript draft. MTBM, WRS, FV, APS, BCAM, and BADBC performed the characterization of the carbohydrates and nutrients. MTBM and BADBC performed the chlorophyll analysis and the sugarcane harvesting. MFB, NGO, and WRS analyzed the whole data and performed the statistical analysis. MTBM, WRS, HBCM, MSB, and APS wrote the final version of the manuscript. HBCM, PAO, WRS, MSB, and AKK provided intellectual input and revised the final version of the manuscript. All authors read and approved the final manuscript. 


\section{Authors' information}

Maria Thereza Bazzo Martins received her MSc in Genomic Sciences from Catholic University of Brasilia. She joined Dr. Hugo Molinari's group in 2008 at Embrapa Agroenergy.

Wagner Rodrigo de Souza received his Ph.D. in Sciences and joined Dr. Molinari's group in 2015 at Embrapa Agroenergy. His interests are in the field of plant abiotic stresses, plant physiology and biochemistry, plant development, bioenergy, senescence, and plant cell wall.

Marcos Fernando Basso received his Ph.D. in Phytopatology from Federal University of Viçosa. He joined Dr. Molinari's group at Embrapa Agroenergy in 2015 to develop new sugarcane cultivars resistant to abiotic stresses and with improved biomass and sucrose accumulation.

Nelson Geraldo de Oliveira is Ph.D. in Agricultural Sciences and has experience in plant nutrition, soil microbiology and field experiments. He is currently working at Embrapa Agroenergy, developing methods to study the performance of transgenic sugarcane in the field.

Bárbara Andrade Dias Brito da Cunha received her MSc. in Plant Biotechnology, Molecular Biology, and Genetics. She is currently a lab manager at Embrapa Agroenergy, acting on gene discovery for sugarcane improvement.

Felipe Vinecky received his Ph.D. in Molecular Biology and joined Dr. Molinari's group in 2015 at Embrapa Agroenergy and his fields of interest are plant abiotic stresses, sucrose accumulation, and biomass.

Polyana Kelly Martins received her Ph.D. in Genetics and Breeding from Federal University of Viçosa. She has experience in Plant Genetics and Biotechnology, and joined Dr. Molinari's group at Embrapa Agroenergy to perform gene discovery for sugarcane improvement, plant genetic transformation, and tissue culture.

Patrícia Abrão de Oliveira received her Ph.D. in Chemistry from USP. She is currently a principal investigator at Embrapa Agroenergy and her field of interest is Phytochemistry.

Bruna Cersózimo Arenque-Musa has Ph.D. in Plant Biochemistry and Ecophysiology from University of Sao Paulo. Her experience relies on plant sink-source relationships and carbon metabolism. She is currently a Scientific Manager at FAPESP (Research Funding Agency of the State of Sao Paulo).

Amanda Pereira De Souza has Ph.D. in Sciences from the University of Sao Paulo (USP). She has experience in Plant Physiology and Biochemistry, focused in carbon metabolism, photosynthesis, and plant cell wall characterization. She is currently a post-doc at University of Illinois at Urbana-Champaign.

Marcos Silveira Buckeridge is a plant biologist and the actual coordinator of the National Institute of Science and Technology of Bioethanol (INCT do Bioetanol). Dr. Buckeridge is currently the President of the Academy of Sciences of the State of São Paulo.

Adilson Kenji Kobayashi is a plant biologist with his Ph.D. from Kobe University. He is currently a principal investigator at Embrapa Agroenergy and his fields of interest are plant abiotic stresses, plant tissue culture and genetic transformation, sugarcane and soybean improvement, and bioenergy.

Betania Ferraz Quirino received her Ph.D. in Cellular and Molecular Biology from University of Winscosin-Madison. She is currently a principal investigator at Embrapa Agroenergy and a professor at Catholic University of Brasilia. Her expertise relies on plant molecular biology, metagenomics, senescence, and plant-pathogen interaction.

Hugo Bruno Correa Molinari received his Ph.D. in Agronomy from Universidade Federal do Paraná (2006). He is currently a principal investigator at Embrapa Agroenergy and his fields of interest are Plant Biochemistry, Molecular Biology, and Genetics, acting on the following subjects: drought stress tolerance, genetic transformation, senescence, plant cell wall, biomass improvement, sucrose accumulation, sugarcane, Setaria viridis, and bioenergy.

\section{Author details}

1 Genetics and Biotechnology Laboratory, Embrapa Agroenergy (CNPAE), Brasília, DF 70770-901, Brazil. 2 Genomic Sciences and Biotechnology Program, Universidade Catolica de Brasilia, Brasília, DF 70790-160, Brazil. 3 Biomass and Biofuel Chemistry Laboratory, Embrapa Agroenergy (CNPAE), Brasília, DF 70770-901, Brazil. 4 Laboratory of Plant Physiological Ecology (LAFIECO), Department of Botany-Institute of Biosciences, University of São Paulo, São Paulo, SP 05508-090, Brazil.

\section{Acknowledgements}

Not applicable.

\section{Competing interests}

The authors declare that they have no competing interests.

Availability of supporting data

The authors ensure the availability of supporting data.

\section{Consent for publication}

The authors have consented for publication.

\section{Funding}

This work was supported by the National Center for Research on Agroenergy (CNPAE), the Brazilian Agricultural Research Corporation (EMBRAPA), and the National Council for Scientific and Technological Development (CNPq). This work is part of the activities of the National Institute of Science and Technology of Bioethanol (http://www.inctdobioetanol.com.br). The authors thank the São Paulo Research Foundation (FAPESP) for financial support.

Received: 15 February 2016 Accepted: 12 July 2016

Published online: 22 July 2016

\section{References}

1. Savage N. Fuel options: the ideal biofuel. Nature. 2011;474:S9-11.

2. Rogelj J, McCollum DL, Reisinger A, Meinshausen M, Riahi K. Probabilistic cost estimates for climate change mitigation. Nature. 2013;493:79-83.

3. Kang Q, Appels L, Tan T, Dewil R. Bioethanol from lignocellulosic biomass: current findings determine research priorities. Sci World J. 2014;2014:1-14.

4. Limayem A, Ricke SC. Lignocellulosic biomass for bioethanol production: current perspectives, potential issues and future prospects. Prog Energ Combust. 2012;38:449-67.

5. Matias de Oliveira D, Finger-Teixeira A, Rodrigues Mota T, Salvador VH, Moreira-Vilar FC, Correa Molinari HB, et al. Ferulic acid: a key component in grass lignocellulose recalcitrance to hydrolysis. Plant Biotechnol J. 2014;13:1224-32.

6. Soccol CR, Vandenberghe LP, Medeiros AB, Karp SG, Buckeridge M, Ramos $L P$, et al. Bioethanol from lignocelluloses: status and perspectives in Brazil. Bioresour Technol. 2010;101:4820-5.

7. De Souza AP, Grandis A, Leite DCC, Buckeridge MS. Sugarcane as a bioenergy source: history, performance, and perspectives for secondgeneration bioethanol. Bioenerg Res. 2014;7:24-35.

8. Zhao XB, Zhang LH, Liu DH. Biomass recalcitrance. Part I: the chemical compositions and physical structures affecting the enzymatic hydrolysis of lignocellulose. Biofuels Bioprod Biorefin. 2012;6:465-82.

9. De Souza AP, Kamei CLA, Torres AF, Pattathil S, Hahn MG, Trindade LM, et al. How cell wall complexity influences saccharification efficiency in Miscanthus sinensis. J Exp Bot. 2015;66:4351-65.

10. Calderan-Rodrigues MJ, Jamet E, Bonassi MB, Guidetti-Gonzalez S, Begossi AC, Setem LV, et al. Cell wall proteomics of sugarcane cell suspension cultures. Proteomics. 2014;14:738-49.

11. Chandel AK, Antunes FA, Anjos V, Bell MJ, Rodrigues LN, Polikarpov I, et al. Multi-scale structural and chemical analysis of sugarcane bagasse in the process of sequential acid-base pretreatment and ethanol production by Scheffersomyces shehatae and Saccharomyces cerevisiae. Biotechnol Biofuels. 2014;7:1-17.

12. Goldemberg J. The Brazilian biofuels industry. Biotechnol Biofuels. 2008;1:1-7.

13. CONAB. Acompanhamento da safra brasileira de cana-de-açúcar; 2015.

14. UNICA. Historical of sugarcane production and milling; 2015.

15. Lima DU, Santos HP, Tine MA, Molle FRD, Buckeridge MS. Patterns of expression of cell wall related genes in sugarcane. Genet Mol Biol. 2001;24:191-8.

16. Buckeridge MS, Souza AP. Breaking the "Glycomic Code" of cell wall polysaccharides may improve second-generation bioenergy production from biomass. Bioenerg Res. 2014;7:1065-73.

17. Tavares EQP, De Souza AP, Buckeridge MS. How endogenous plant cell-wall degradation mechanisms can help achieve higher efficiency in saccharification of biomass. J Exp Bot. 2015:66:4133-43. 
18. Grandis A, Souza AP, Tavares EQP, Buckeridge MS. Using natural plant cell wall degradation mechanisms to improve second generation bioethanol. In: McCann CM, Buckeridge SM, Carpita CN, editors. Plants and bioenergy. New York: Springer; 2014. p. 211.

19. Zhang HS, Zhou CJ. Signal transduction in leaf senescence. Plant Mol Biol. 2013;82:539-45.

20. Liu J, Wu YH, Yan JJ, Liu YD, Shen FF. Protein degradation and nitrogen remobilization during leaf senescence. J Plant Biol. 2008;51:11-9.

21. Maillard A, Diquelou S, Billard V, Laine P, Garnica M, Prudent M, et al. Leaf mineral nutrient remobilization during leaf senescence and modulation by nutrient deficiency. Front Plant Sci. 2015;6:1-15.

22. Lim PO, Kim HJ, Nam HG. Leaf senescence. Annual review. Plant Biol. 2007;58:115.

23. Martins NF, Patil S, Molinari HBC, Dias BBA, Martins MTB, Quirino FB, et al. Expression profilin using Affymetrix GeneChip Microarrays in sugarcane during leaf senescence. In: Genética SBD, editor. Simpósio Brasileiro de Genética Molecular de Plantas. Ilhéus; 2011. p. 12.

24. Jung JH, Fouad WM, Vermerris W, Gallo M, Altpeter F. RNAi suppression of lignin biosynthesis in sugarcane reduces recalcitrance for biofuel production from lignocellulosic biomass. Plant Biotechnol J. 2012;10:1067-76.

25. Murad AM, Molinari HB, Magalhaes BS, Franco AC, Takahashi FS, de Oliveira NG, et al. Physiological and proteomic analyses of Saccharum spp. grown under salt stress. PLoS ONE. 2014;9:e98463.

26. Kuijper J. DeGroei van Bladschijf, Bladscheede em Stengel van het suikerriet. Archives Suikerind Ned Indië. 1915;23:528-56.

27. Argenta G, da Silva PRF, Bortolini CG, Forsthofer EL, Strieder ML. Relationship of reading of portable chlorophyll meter with contents of extractable chlorophyll and leaf nitrogen in maize. Revista Brasileira de Fisiologia Vegetal. 2001;13:158-67.

28. Henry GAF, Grime JP. Methods in comparative plant ecology: a laboratory manual. New York: Springer; 1993.

29. Lichtenthaler HK. Chlorophylls and carotenoids, the pigments of photosynthetic biomembranes. Methods Enzymol. 1987;148:350-82.

30. Beaufils ER, Sumner ME. Application of the DRIS approach for calibrating soil, plant yield and plant quality factors in sugarcane. In: Proceedings of the South African Sugar Technologists'Association; 1976. p. 1-7.

31. Adler PR, Wilcox GE. Rapid perchloric acid digest methods for analysis of major elements in plant tissue. Commun Soil Sci Plant Anal. 1985;16:1153-63.

32. Persson JA, Wennerholm M, O'Halloran S. Handbook for Kjeldahl digestion: a recent review of the classical method with improvements developed by FOSS. CA Andersson, Malmoe, Sweden: FOSS, DK-3400 Hilleroed, Denmark; 2008.

33. De Souza AP, Leite DCC, Pattathil S, Hahn MG, Buckeridge MS. Composition and structure of sugarcane cell wall polysaccharides: implications for second-generation bioethanol production. Bioenerg Res. 2013;6:564-79.

34. Dubois M, Gilles KA, Hamilton JK, Rebers PA, Smith F. Calorimetric method for determination of sugars and related substances. Anal Chem. 1956;28:350-6.

35. StatSoft I. STATISTICA (data analysis software system), version 10; 2011.

36. Park JH, Oh SA, Kim YH, Woo HR, Nam HG. Differential expression of senescence-associated mRNAs during leaf senescence induced by different senescence-inducing factors in Arabidopsis. Plant Mol Biol. 1998;37:445-54

37. Weaver LM, Gan SS, Quirino B, Amasino RM. A comparison of the expression patterns of several senescence-associated genes in response to stress and hormone treatment. Plant Mol Biol. 1998;37:455-69.

38. Vettore AL, Silva FRD, Kemper EL, Arruda P. The libraries that made SUCEST. Genet Mol Biol. 2001;24:1-7.

39. Schmittgen TD, Livak KJ. Analyzing real-time PCR data by the comparative C(T) method. Nat Protoc. 2008;3:1101-8.

40. Iskandar HM, Simpson RS, Casu RE, Bonnett GD, Maclean DJ, Manners JM. Comparison of reference genes for quantitative real-time polymerase chain reaction analysis of gene expression. Plant Mol Biol Rep. 2004;22:325-37.

41. Reis RR, Brito Andrade Dias, da Cunha B, Martins PK, Martins MTB, Alekcevetch JC, Chalfun-Júnior A, et al. Induced over-expression of AtDREB2A CA improves drought tolerance in sugarcane. Plant Sci. 2014;221-222:59-68.
42. Lennartsson PR, Erlandsson P, Taherzadeh MJ. Integration of the first and second generation bioethanol processes and the importance of byproducts. Bioresour Technol. 2014;165:3-8.

43. Pereira SC, Maehara L, Machado CMM, Farinas CS. 2G ethanol from the whole sugarcane lignocellulosic biomass. Biotechnol Biofuels. 2015;8:1-16.

44. Sage RF, Peixoto MM, Sage TL. Photosynthesis in sugarcane. In: Moore PH, Botha FC, editors. Sugarcane: physiology, biochemistry and functional biology. 1st ed. New York: Wiley; 2014. p. 121

45. Kingston G. Mineral nutrition of sugarcane. In: Moore PH, Botha FC, editors. Sugarcane: physiology, biochemistry and functional biology. 1st ed. New York: Wiley; 2014. p. 85

46. Masclaux C, Valadier MH, Brugiere N, Morot-Gaudry JF, Hirel B. Characterization of the sink/source transition in tobacco (Nicotiana tabacum L.) shoots in relation to nitrogen management and leaf senescence. Planta. 2000;211:510-8.

47. Santos EFD, Donha RMA, Araújo CMMD, Lavres Junior J, Camacho MA Faixas normais de nutrientes em cana-de-açúcar pelos métodos ChM, DRIS e CND e nível crítico pela distribuição normal reduzida. Revista Brasileira de Ciência do Solo. 2013;37:1651-8.

48. Calcino DV. Australian sugarcane nutrition manual: sugar research and development corporation and bureau of sugar experiment stations; 1994.

49. Hill J, Robson AD, Loneragan JF. The effect of copper supply on the senescence and the retranslocation of nutrients of the oldest leaf of wheat. Ann Bot. 1979;44:279-87.

50. Prado RM. Manual de Nutrição de Plantas Forrageiras. FUNEP: Jaboticabal; 2008.

51. Malavolta E, Vitti GC, Oliveira SA. Avaliação do estado nutricional das plantas: príncipios e aplicações. 2nd ed. Piracicaba: Associação Brasileira para Pesquisa da Potassa e do Fosfato; 1997.

52. Van Raij B, Cantarella H, Quaggio JA, Furlani AMC. Recomendações de adubação e calagem para o estado de São Paulo. 2nd ed. Campinas: Instituto agronômico e Fundação IAC; 1996.

53. Himelblau E, Amasino RM. Nutrients mobilized from leaves of Arabidopsis thaliana during leaf senescence. J Plant Physiol. 2001;158:1317-23.

54. Hocking PJ, Pate JS. Mobilization of minerals to developing seeds of legumes. Ann Bot. 1977:41:1259-78.

55. Waters BM, Grusak MA. Whole-plant mineral partitioning throughout the life cycle in Arabidopsis thaliana ecotypes Columbia, Landsberg erecta, Cape Verde Islands, and the mutant line ys/7ys/3. New Phytol. 2008; 177:389-405.

56. Moreira A, Fageria NK. Yield, uptake, and retranslocation of nutrients in banana plants cultivated in upland soil of Central Amazonian. J Plant Nutr. 2009;32:443-57

57. Distelfeld A, Avni R, Fischer AM. Senescence, nutrient remobilization, and yield in wheat and barley. J Exp Bot. 2014:65:3783-98.

58. Franco HCJ, Pimenta MTB, Carvalho JLN, Magalhães PSG, Rossell CEV, Braunbeck $O A$, et al. Assessment of sugarcane trash for agronomic and energy purposes in Brazil. Scientia Agricola. 2013;70:305-12.

59. Demattê JLI. Cultura da cana-de-açúcar. Recuperação e manutenção da fertilidade do solo Encarte Técnico_-Informações agronômicas. 2005;1:1-24.

60. Grbic $V$, Bleecker AB. Ethylene regulates the timing of leaf senescence in Arabidopsis. Plant J. 1995:8:595-602.

61. Pontier D, Gan SS, Amasino RM, Roby D, Lam E. Markers for hypersensitive response and senescence show distinct patterns of expression. Plant Mol Biol. 1999;39:1243-55.

62. He Y, Fukushige $H$, Hildebrand DF, Gan S. Evidence supporting a role of jasmonic acid in Arabidopsis leaf senescence. Plant Physiol. 2002;128:876-84.

63. Diaz C, Purdy S, Christ A, Morot-Gaudry JF, Wingler A, Masclaux-Daubresse C. Characterization of markers to determine the extent and variability of leaf senescence in Arabidopsis. A metabolic profiling approach. Plant Physiol. 2005;138:898-908.

64. Cai P, Qian Q, Kang Z, Zhang Z, Wang G. Construction of eukaryotic plant expression vector with the SAG12 promoter and the leaf senescencerelated IPT gene and its genetic transformation in rice. Pak J Bot. 2012;44:2041-6. 
65. Gan S, Amasino RM. Inhibition of leaf senescence by autoregulated production of cytokinin. Science. 1995;270:1986-8.

66. Eklöf JM, Brumer $\mathrm{H}$. The XTH gene family: an update on enzyme structure, function, and phylogeny in xyloglucan remodeling. Plant Physiol. 2010;153:456-66.

67. Ferreira SS, Hotta CT, Poelking VG, Leite DC, Buckeridge MS, Loureiro $\mathrm{ME}$, et al. Co-expression network analysis reveals transcription factors associated to cell wall biosynthesis in sugarcane. Plant Mol Biol. 2016;5:1-9.

68. Christiansen MW, Gregersen PL. Members of the barley NAC transcription factor gene family show differential co-regulation with senescence-associated genes during senescence of flag leaves. J Exp Bot. 2014;65:4009-22.

69. Kajimura T, Mizuno N, Takumi S. Utility of leaf senescence-associated gene homologs as developmental markers in common wheat. Plant Physiol Biochem. 2010;48:851-9.

70. Gregersen PL, Holm PB. Transcriptome analysis of senescence in the flag leaf of wheat (Triticum aestivum L.). Plant Biotechnol J. 2007:5:192-206.
71. Parrott DL, McInnerney K, Feller U, Fischer AM. Steam-girdling of barley (Hordeum vulgare) leaves leads to carbohydrate accumulation and accelerated leaf senescence, facilitating transcriptomic analysis of senescenceassociated genes. New Phytol. 2007;176:56-69.

72. Jukanti AK, Fischer AM. A high-grain protein content locus on barley (Hordeum vulgare) chromosome 6 is associated with increased flag leaf proteolysis and nitrogen remobilization. Physiol Plantarum. 2008;132:426-39.

73. Hollmann J, Gregersen PL, Krupinska K. Identification of predominant genes involved in regulation and execution of senescence-associated nitrogen remobilization in flag leaves of field grown barley. J Exp Bot. 2014:65:3963-73.

74. Nose M, Watanabe A. Clock genes and diurnal transcriptome dynamics in summer and winter in the gymnosperm Japanese cedar (Cryptomeria japonica (L.f.) D.Don). BMC Plant Biol. 2014;14:1-19.

75. Hosoo Y, Yoshida M, Yamamoto H. Effect of light intensity on diurnal differences in the supply of cell wall components to the innermost surface of developing S2 layers of tracheids in Cryptomeria japonica. J Wood Sci. 2011;57:345-51.

\section{Submit your next manuscript to BioMed Central and we will help you at every step:}

- We accept pre-submission inquiries

- Our selector tool helps you to find the most relevant journal

- We provide round the clock customer support

- Convenient online submission

- Thorough peer review

- Inclusion in PubMed and all major indexing services

- Maximum visibility for your research

Submit your manuscript at www.biomedcentral com/submit 